\title{
Reproduction of invasive Loricariichthys platymetopon Isbrücker \& Nijssen, 1979 (Actinopterygii, Loricariidae) on the upper Paraná River floodplain
}

\author{
Camila Antoniassi Cardim ${ }^{1}$ \\ Vanessa de Brito Pereira ${ }^{2}$ \\ Herick Soares de Santana ${ }^{3}$ \\ Claudenice Dei Tos ${ }^{3 *}$ \\ ${ }^{1}$ Universidade Estadual de Maringá, Curso de Graduação em Ciências Biológicas \\ Departamento de Biologia, Maringá - PR, Brasil \\ ${ }^{2}$ Departamento de Áreas Acadêmicas, Instituto Federal de Goiás, campus Águas Lindas de Goiás \\ Rua 21, Jardim Querência, CEP 72.910-733, Águas Lindas de Goiás - GO, Brasil \\ ${ }^{3}$ Universidade Estadual de Maringá, DBI/NUPELIA \\ Avenida Colombo, 5790, Bloco H90, sala 7B, CEP 87.020-900 Maringá - PR, Brasil \\ Autor para correspondência \\ claudenice@nupelia.uem.br”
}

Submetido em 18/06/2018

Aceito para publicação em 24/01/2019

\section{Resumo}

Reprodução da invasora Loricariichthys platymetopon Isbrücker \& Nijssen, 1979 (Actinopterygii, Loricariidae) da planície de inundação do alto rio Paraná. Loricariichthys platymetopon ocorria originalmente nos rios Uruguai, Paraguai e baixo Paraná. Com a formação do reservatório de Itaipu em 1982, invadiu e colonizou o alto rio Paraná. Usando os dados obtidos trimestralmente em nove pontos de amostragem na planície de inundação do alto rio Paraná, foram caracterizadas as fases reprodutivas e células germinativas das fêmeas de L. platymetopon. Além disso, foram verificados: a variação no diâmetro dos oócitos, a fecundidade dos lotes, a fecundidade relativa dos lotes por comprimento padrão e peso total e os locais de reprodução na planície de inundação do alto rio Paraná. Foram registrados os estágios: oogônia única, cistos de oogônias e oócitos, oócitos de crescimento primário inicial, intermediário e final, oócitos de crescimento completo e oócitos maduros. As fases reprodutivas foram validadas pelos atributos das células germinativas e as fêmeas foram registradas nas seguintes fases: desenvolvimento, apto à desova, regressão e regeneração. O diâmetro dos oócitos variou de 100 a $4.100 \mu \mathrm{m}$. A fecundidade do lote variou de 372 a 1.392 oócitos. $^{-1}$ e a estimativa da fecundidade relativa do lote por comprimento padrão foi de 16 a 49 oócitos. $\mathrm{cm}^{-1} \mathrm{e}$, em peso foi de 3,6 a 6,4 oócitos.g ${ }^{-1}$. Os padrões reprodutivos de L. platymetopon na planície de inundação do alto rio Paraná mostraram os locais onde a atividade reprodutiva é mais intensa (lagoas do Guaraná, das Garças e Fechada e rio Baía) e locais onde é menos intensa (rios Ivinheima e Paraná). Assim, a resistência biótica do rio Ivinheima, devido à integridade desses ambientes nessa área, que faz parte da Área de Proteção Ambiental das Ilhas e Várzeas do Rio Paraná, tem impedido o sucesso reprodutivo desta invasora.

Palavras-chave: Espécies invasoras; Fecundidade; Oogênese; Reprodução de peixes 


\section{Abstract}

Loricariichthys platymetopon originally occurred in the Uruguay, Paraguay and lower Paraná rivers. With the formation of Itaipu Reservoir in 1982, it invaded and colonized the upper Paraná River. Using the data obtained quarterly at nine sampling sites on the upper Paraná River floodplain, the reproductive phases and the germ cells of L. platymetopon females were characterized. Variation in oocyte diameter, batch fecundity, and relative batch fecundity by standard length and total weight was also verified, as well as the reproduction sites on the upper Paraná River floodplain. The following stages were recorded: single oogonia, oogonial and oocytes cysts, initial, intermediate and final primary growth oocytes, full-grown oocytes and maturation oocytes. The reproductive phases were validated by the germ cell attributes and females were recorded in the following phases: developing, spawning-capable, regression and regeneration. Oocyte diameters varied from 100 to $4100 \mu \mathrm{m}$. Batch fecundity varied from 372 to 1392 oocytes. $\mathrm{g}^{-1}$ and the relative batch fecundity estimate by length was 16 to 49 oocytes.cm ${ }^{-1}$ and by weight was 3.6 to 6.4 oocytes. $\mathrm{g}^{-1}$. The reproductive patterns of $L$. platymetopon on the upper Paraná River floodplain showed the sites where reproductive activity is more intense (Guaraná, Garças and Fechada lagoons and the Baía River) and sites where it is less intense (Ivinheima and Paraná rivers). Thus, the biotic resistance of the Ivinheima River, due to the integrity of these environments, which is part of the Environmental Protection Area of the Islands and Marshes of the Paraná River, has prevented the reproductive success of this invader.

Key words: Fecundity; Fish reproduction; Invasive species; Oogenesis

\section{Introduction}

Biological invasion is a major concern for ecologists, since invasive species can cause environmental damage (e.g., loss of native species and loss of ecosystem services), as well as economic harm (PEJCHAR; MOONEY, 2009; SIMBERLOFF et al., 2013). Various hypotheses try to explain invasive success from an environmental perspective and from an invasive species position (BARNEY; WHITLOW, 2008). Understanding these processes is fundamental to the adequate implementation of precautionary and management measures to minimize the impact of these species.

Various problems related to invasive species (e.g., aquatic macrophytes; fish such as carp and tilapia) have been recorded in freshwater aquatic environments (AGOSTINHO et al., 2007; GALLARDO et al., 2016), leading to irreversible problems, since once established it is very difficult to eliminate the species from an environment. There was a massive invasion of 33 fish species in the Paraná River after the suppression of a natural barrier that separated the fish faunas of the lower and upper stretches (sensu ABELL et al., 2008). These species colonized the upper Paraná after the formation of Itaipu Reservoir (JULIO JR. et al., 2009).
Among these species, Loricariichthys platymetopon Isbrücker \& Nijssen, 1979 was originally distributed in the basins of the Paraguay, Uruguay and lower Paraná rivers (REIS; PEREIRA, 2000) and became one of the most abundant on the upper Paraná River floodplain (DEI TOS et al., 1997; SUZUKI et al., 2000; OLIVEIRA et al., 2001). In addition, this species increased its geographic range and reached several upstream reservoirs in the Paranapanema River (MARCUCCI et al., 2005; SOUTO et al., 2011; CASIMIRO et al., 2017). Skóra et al. (2015) comment that 22 other non-native species were introduced in the upper Paraná River by other vectors, such as fish stocking, aquaculture and release from aquarists, totaling 55 species.

As it is a detritivorous species, L. platymetopon carries out a fundamental role in the nutrient cycling and food web of the sites where it occurs (FUGI et al., 1996; HAHN et al., 2004; TONELLA et al., 2018). It is also prey for larger fish species, birds and mammals and has potential commercial value (QUEROL et al., 1996).

Reproductive strategy is one factor that facilitates the invasive success of a certain species, which can include traits such as length at sexual maturity, life span, spawning month, fecundity, egg diameter and hatching time (WOOTTON, 1984). Loricariichthys platymetopon larvae hatch very developed, in the post-flexion stage 
(NAKATANI et al., 2001). Reproductive strategies are largely inheritable traits, linked to the environment, genotype expression and intraspecific spatial and temporal variation related to the influence of biotic and abiotic factors. These traits are often correlated, and presumably optimized, by natural selection (for revision see MCBRIDE et al., 2015).

The reproductive activity of $L$. platymetopon can vary from year to year, demonstrating high variability between sites. For example, on the upper Paraná River floodplain, the greatest reproductive activity was from October to January and from October to February in the first and second period of evaluation, respectively (DEI TOS et al., 1997). These inter-annual variations were related to the intensity and duration of the flood in the reproductive period. Other periods of evaluation for this species on this floodplain showed some reproductive activity from January to August (highly seasonal). More than $30 \%$ of the individuals were in reproduction in October, November and December (SUZUKI et al., 2004). Marcucci et al. (2005), for example, demonstrated in Capivara Reservoir in two study periods that this species reproduces between November and February and December and March, coinciding with a higher rainfall. Investigation of this species in Saraiva Lagoon, Ilha Grande National Park (states of Mato Grosso do Sul and Paraná), showed reproductive activity from September to February (BAILLY et al., 2011). Records from a reservoir on Nova Esperança Ranch, Santana Velha, Uruguaiana (state of Rio Grande do Sul) demonstrate reproductive activities of $L$. platymetopon from November to February (QUEROL et al., 2002). The reproductive strategies of this invader showed alterations in size at first maturation, spawning period and other strategies, such as male care of the egg mass (conservative for this species).

Despite the large number of articles characterizing reproductive aspects of L. platymetopon, little is known, based on light microscopy, about its germ cells, oocyte development and spawning periods. The spawning sites were evaluated on the upper Paraná River floodplain by Dei Tos et al. (1997) and Suzuki el al. (2004); but after so much time the species may have managed to advance into different sites (e.g., the tributaries). This information is essential to understand how the reproductive framework of the species contributes to its invasive success and high abundance in diverse environments. Thus, this study aims to: i) describe the germ cells of L. platymetopon females; ii) recognize the reproductive phases through the macroscopic and microscopic characteristics of the ovary and gonadosomatic index; iii) verify the variation in oocyte diameter; iv) estimate batch fecundity and relative batch fecundity by standard length and total weight of the population; and v) determine the reproduction sites during the period of investigation on the upper Paraná River floodplain. For this, the reproductive profile of $L$. platymetopon was traced using several macroscopic and microscopic morphological characteristics of the ovary. Reproductive success was evaluated in different areas of the upper Paraná River floodplain through estimates of fecundity, the gonadosomatic index (GSI) and reproductive phases.

\section{Material and Methods}

\section{Study area}

The samples were collected quarterly (March, June, September and December 2013, 2014 and 2015) (12 samples) on the upper Paraná River floodplain. This stretch of floodplain comprises the only undammed stretch of the Paraná River in Brazil, with the Baía and Ivinheima rivers being fundamental to the maintenance of species biodiversity and floodplain habitat heterogeneity (AGOSTINHO; ZALEWSKI, 1996; REYNALTETATAJE et al., 2013). Sampling was carried out at nine sites (Figure 1): three rivers (Paraná 2245'39.96”S, 53¹5'7.44”W; Baía 2243’23.16”S, 53¹7’25.5”W and Ivinheima $22^{\circ} 47^{\prime} 59.64^{\prime \prime S}, 53^{\circ} 32^{\prime 2} 21.3^{\prime \prime} \mathrm{W}$ ), four open lagoons (Patos 22\%49'33.66"S, 5333"9.9'W; Guaraná 22043'16.68"S, 5318'9.24"W; Garças $22^{\circ} 43^{\prime} 27.18^{\prime \prime}$ 'S, 53 $13^{\circ} 4.56^{\prime \prime W}$ and Ressaco do Pau Véio $\left.22^{\circ} 44^{\prime} 50.76^{\prime \prime S}, 53^{\circ} 15^{\prime} 11.16^{\prime \prime} \mathrm{W}\right)$ and two closed lagoons (Fechada 22 42 '37.92'S, 53 ${ }^{\circ} 16^{\prime} 33.06^{\prime \prime} \mathrm{W}$ and Ventura $\left.22^{\circ} 51^{\prime} 23.7^{\prime \prime} \mathrm{S}, 53^{\circ} 36^{\prime} 1.02^{\prime \prime} \mathrm{W}\right)$. This investigation was performed in partnership with ILTER (International Long Term Ecological Research)/CNPq (National Council for Scientific and Technological Development) - Site 6. 
FIGURE 1: Study area and location of the sampling site on the upper Paraná River floodplain.

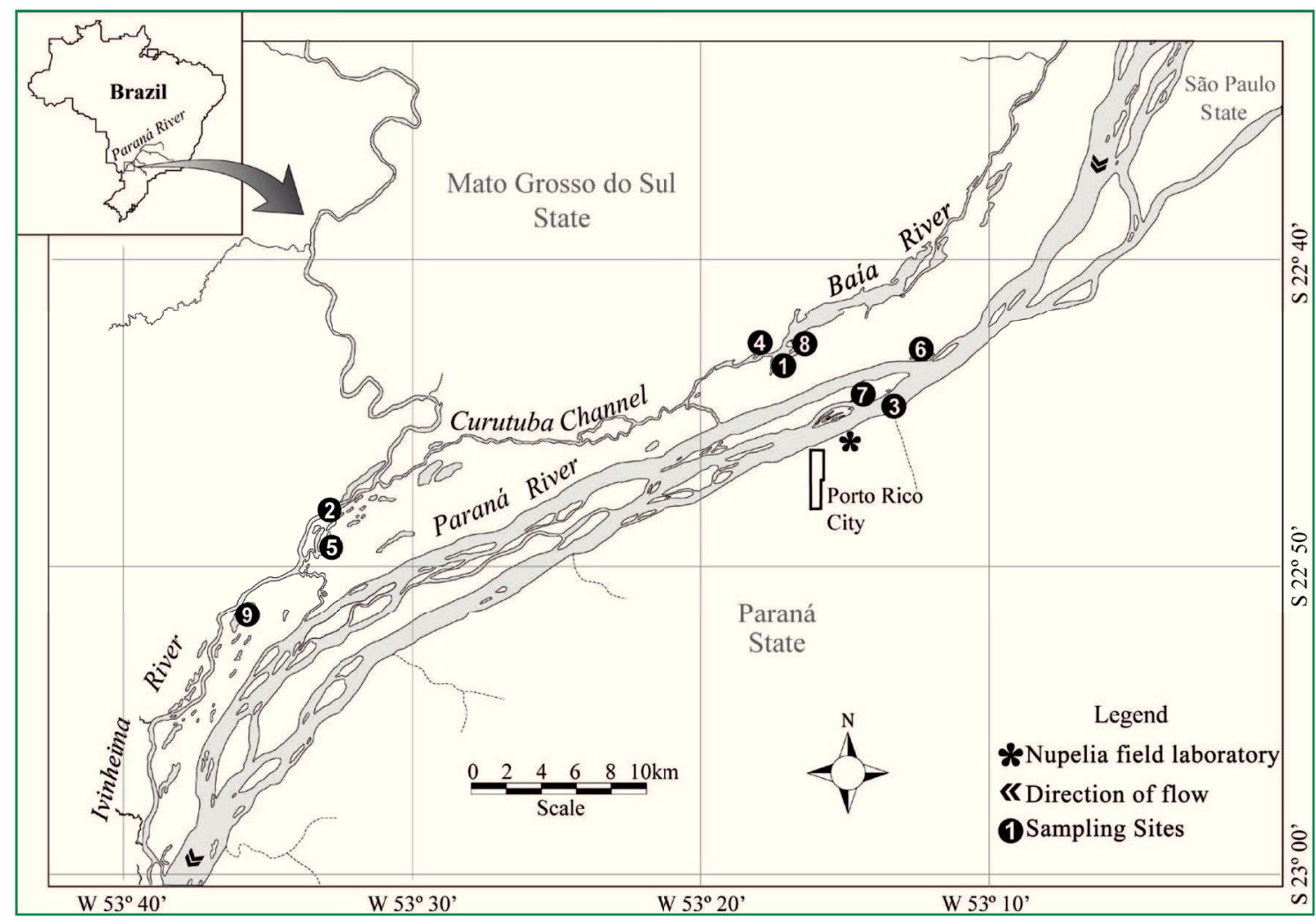

Legend: Baía River - 1; Ivinheima River - 2; Paraná River - 3; Guaraná Lagoon - 4; Patos Lagoon - 5; Garças Lagoon - 6; Ressaco do Pau Véio Lagoon - 7; Fechada Lagoon - 8; Ventura Lagoon - 9.

\section{Sampling}

The females were sampled using 11 single-mesh gillnets $(2.4,48),(3,30),(4,30),(5,30),(6,30),(7$, $35),(8,32),(10,34),(12,31),(14,34)$ and $(16,34) \mathrm{cm}$ between adjacent knots/square meters, respectively in the years of sampling. The nets were exposed for $24 \mathrm{~h}$ at each site. The samples were removed every $8 \mathrm{~h}$ in the lagoons and channels associated with the Paraná, Baía and Ivinheima rivers. In order to complement the sampling and catch smaller individuals, single trawls were carried out during the day (mesh $=0.5 \mathrm{~cm} ; 20 \mathrm{~m}$ long; stretched height $=3 \mathrm{~m}$ ) in the marginal areas (mean $\left.=217.91 \mathrm{~m}^{2} ; \mathrm{SD} \pm 48.70\right)$ of the lagoons. The specimens were anesthetized with $0.1 \%$ benzocaine, following the protocols approved by the CEUA (Committee for the Ethical Use of Animals, 051/2010-PPG/UEM).

Standard length $(\mathrm{cm})$, total weight $(\mathrm{g})$ and weight of the ovaries $(\mathrm{g})$ were recorded for each individual.
The gonadal development phase of each individual was determined macroscopically, considering the size and shape of the ovary, occupation in the abdominal cavity, evidence of vascularization, color, visualization of the oocytes and flaccidity, according to Brown-Peterson et al. (2011) and Quagio-Grassiotto et al. (2013).

A sample from each ovary was fixed in Bouin solution for histological studies and a sample from a spawning capable ovary was fixed in $10 \%$ buffered formalin to estimate oocyte diameter and fecundity. During the histological procedures, the ovaries were dehydrated in ethanol, embedded in Historesin (Leica) and cross-sectioned ( $4 \mu \mathrm{m}$ thick; 2 replicas for staining). The sections were stained using Periodic Acid Schiff (PAS)/ hematoxylin/metanil yellow (QUINTERO-HUNTER et al., 1991) and $0.5 \%$ Toluidine Blue (VIDAL, 1987; MELLO; VIDAL, 1980). The recordings of germ cell development and gonadal development phases were carried out using a microscope coupled to a camera and a 
computer with an image capture program. The calibration of the scales was done using Image-Pro Plus.

The terminology to identify the steps and stages of the germ cells found for L. platymentopon followed Grier et al. (2009) and Quagio-Grassiotto et al. (2011). The reproductive phases were attributed based on the maturity stages of the germ cells according to BrownPeterson et al. (2011) for marine Perciformes and adapted for Neotropical freshwater fish by QuagioGrassiotto et al. (2013) and Wildner et al. (2013). The gonadosomatic index (GSI) was calculated for each individual and used to evaluate the variation in the different reproductive phases. The index was calculated according to the equation: $\mathrm{GSI}=\mathrm{GW} / \mathrm{TW} * 100$, where $\mathrm{GW}=$ gonad weight and TW $=$ total weight. Three 0.3 $\mathrm{g}$ samples were removed from the anterior, middle and posterior region of the right ovary of 18 individuals to estimate fecundity. The oocytes were then separated, measured on a micrometric scale and counted under a stereomicroscope. Batch fecundity $\left(\mathrm{F}_{\mathrm{B}}\right)$ and relative batch fecundity (number of developing oocytes divided by fish body weight $\left[\mathrm{g}^{-1}\right]$ and standard length $\left[\mathrm{cm}^{-1}\right]$ ) were estimated using gravimetric analysis based on the relation between ovary weight and the oocyte density in the ovary (VAZZOLER, 1996; MURUA et al., 2003). The number of eggs spawned per batch (batch fecundity) was estimated based on oocyte size larger than $2500 \mu \mathrm{m}$.
The description of the main reproduction sites of the species was done using the female abundance in each reproductive phase found at each sampled site.

\section{Results}

A total of 1101 females were sampled. Standard length ranged from 5.3 to $29.5 \mathrm{~cm}$ and total weight from 4.2 to $242.8 \mathrm{~g}$. The macroscopic characteristics of the ovary of L. platymetopon showed a hollow, paired, elongated, saccular organ suspended dorsally within the coelom by the mesovarioum. The ovary anatomically varied in appearance at different times in the reproductive cycle. The following phases were recorded: immature, developing, spawning capable, regressing and regenerating. During the reproductive cycle, the GSI ranged from an average of 0.36 to 5.03 (Table 1).

The morphology of the germ cells of the ovary of 255 individuals was examined through light microscopy. The oogenesis of L. platymetopon was characterized by the development stages oogonial proliferation, primary growth oocytes, secondary growth [vitellogenesis] oocytes and oocyte maturation (Table 2; Figure 2). The oogonia divide and form cell nests in the germinal epithelium. These nests consist of batches of germ cells (oogonia and oocytes) and pre-follicle cells.

TABLE 1: Diagnosis of the reproductive phases of $L$. platymetopon females from the upper Paraná River floodplain.

\begin{tabular}{ll}
\hline \multicolumn{1}{c}{ Phases } & \multicolumn{1}{c}{ Macroscopic diagnosis } \\
\hline Immature & Small ovaries, filamentous, translucent, blood vessels indistinct $(\mathrm{GSI}=0.36 ; \mathrm{SD} \pm 0.19 ; \mathrm{N}=39)$. \\
\hline Developing & Ovaries in expansion, blood vessels more evident $(\mathrm{GSI}=1.35 ; \mathrm{SD} \pm 1.34 ; \mathrm{N}=330)$. \\
\hline Spawning capable & $\begin{array}{l}\text { Large ovaries, evident blood vessels, which almost completely occupied the coelomic cavity, } \\
\text { macroscopically visible opaque and translucent oocytes }(\mathrm{GSI}=5.03 ; \mathrm{SD} \pm 2.29 ; \mathrm{N}=373) .\end{array}$ \\
\hline Regressing & Flaccid ovaries and blood vessels evident $(\mathrm{GSI}=1.03 ; \mathrm{SD} \pm 0.69 ; \mathrm{N}=215)$. \\
\hline Regenerating & $\begin{array}{l}\text { Small ovaries, thicker ovarian wall, reduced blood vessels, but present }(\mathrm{GSI}=0.54 ; \mathrm{SD} \pm 0.48 ; \\
\mathrm{N}=71) .\end{array}$ \\
\hline
\end{tabular}


FIGURE 2: Light microphotography representative of stages and steps of germ cells of L. platymetopon females from the upper Paraná River floodplain.
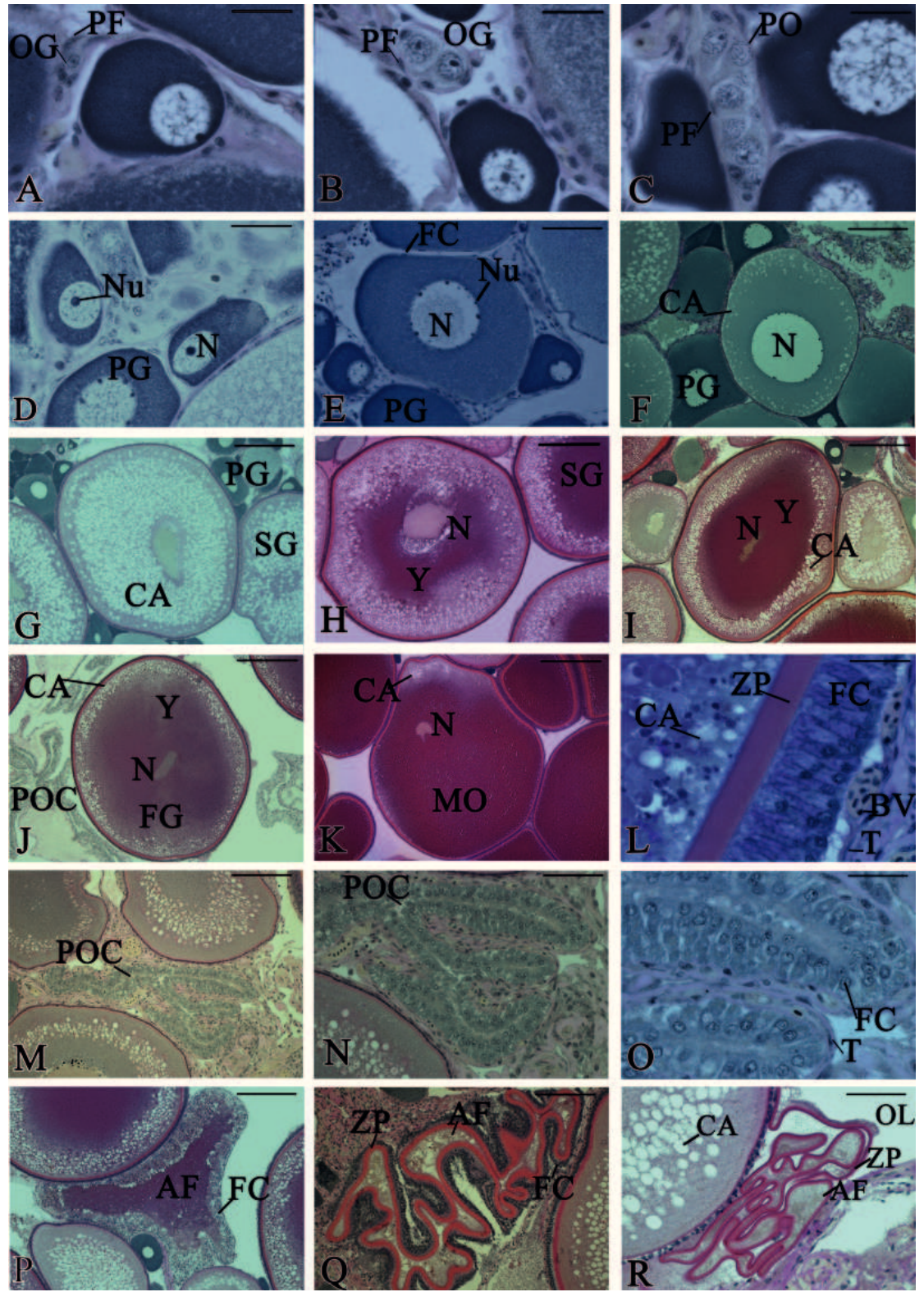

Legend: A. Single oogonium surrounded by pre-follicle cells $(\mathrm{PF})$, bar $=30 \mu \mathrm{m}$; B. Oogonial cysts, bar $=30 \mu \mathrm{m}$; C. Germline cysts containing oocytes in pachytene (PO) delimited by pre-follicle cells $(\mathrm{PF})$, bar $=30 \mu \mathrm{m}$; D. Primary growth oocyte with single nucleolus, bar $=30 \mu \mathrm{m}$; E. Primary growth oocyte with perinuclear nucleoli, bar $=70 \mu \mathrm{m} ; \mathbf{F}$. Primary growth oocyte initiating the formation of cortical alveoli, bar $=140$ $\mu \mathrm{m}$; G. Early secondary growth oocyte with its ooplasm full of cortical alveoli and a regular nucleus, bar $=280 \mu \mathrm{m} ; \mathbf{H}$. Intermediate secondary growth oocytes with a thick layer of cortical alveoli and yolk deposition (Y), and a regular nucleus, bar $=280 \mu$ m; I. Final secondary growth oocytes with a thinner layer of cortical alveoli, greater yolk deposition $(\mathrm{Y})$ and an irregular nucleus, bar $=350 \mu \mathrm{m}$; J. Full-grown oocyte (FG) with cortical alveoli more peripherical in the ooplasm, more abundant yolk and an eccentric irregular nucleus, bar $=350 \mu \mathrm{m} ; \mathbf{K}$. Oocyte maturation $(\mathrm{OM})$ with ooplasm abundant in yolk, the cortical alveoli perpherical and an eccentric irregular nucleus migrates to the periphery of the ooplasm in the animal pole, bar $=560 \mu \mathrm{m} ; \mathbf{L}$. Detail of the envelopes of a maturing oocyte $(\mathrm{OM})$ showing the zona pellucida $(\mathrm{ZP})$, follicle cells $(\mathrm{FC})$ and thecal cells $(\mathrm{T}), \mathrm{bar}=30 \mu \mathrm{m} ; \mathbf{M}$. Post-ovulatory follicle complex (POC), bar $=140 \mu \mathrm{m} ; \mathbf{N}$. Detail of post-ovulatory follicle complex (POC), bar $=70 \mu \mathrm{m} ; \mathbf{O}$. Detail of post-ovulatory follicle complex showing follicle cells (FC) and thecal cells (T), bar $=30 \mu \mathrm{m} ; \mathbf{P}$. Atresic follicle (AF) with follicle cell, vestige of yolk and little evidence of zona pellucida, bar $=280 \mu \mathrm{m} ; \mathbf{Q}$. Atresic follicle (AF) showing the zona pellucida, very clear follicle cell and rupture of the ooplasmic components, bar $=140 \mu \mathrm{m} ; \mathbf{R}$. Atresic follicle (AF) showing the zona pellucida clearly, vestigial ooplasmic component and absence of follicle cells, bar $=70 \mu \mathrm{m}$. PG, primary growth oocytes, $\mathbf{S G}$, secondary growth oocytes, $\mathbf{P F}$, pre-follicle cell, FC, follicle cell, Y, yolk, N, nucleus, Nu, nucleolus, BV, blood vessel. Staining: PAS+hematoxylin+metanil yellow (A-R). 
TABLE 2: Diagnosis of the different stages of oocyte development of L. platymetopon females from the upper Paraná River floodplain.

\section{Stages}

Oogonia/Oocytes

Primary growth

\section{Diagnosis}

The oogonium is surrounded by pre-follicle epithelial cells (Fig. 2A) proliferated by mitosis (Fig. 2B) and a cyst of cells formed in the ovarian stroma (Fig. 2B). The oocytes in the first meiotic division (Fig. 2C) were recorded in pachytene.

Primary growth was marked by ooplasmatic basophilia and a nucleus with a single nucleolus (Fig. 2D), perinuclear nucleoli (Fig. 2E) and the start of the formation of the cortical alveoli (Fig. 2F).

Secondary growth (Fig. 2G-J) was characterized by vitellogenesis, in which vitellogenin derived from yolk globules starts to accumulate in the ooplasm and leads to an increase in the oocytes, which, in turn, leads to the formation of initial (Fig. 2G), intermediate (Fig. 2H) and final (Fig. 2I) secondary growth oocytes and full-grown oocytes (Fig. 2J).

Mature oocyte (Fig. 2K) with the nucleus in the animal pole and detail of the surrounding follicle cells and a theca in the zona pellucida (Fig. 2L). During ovulation the mature oocyte moves from the follicle to the ovarian lumen and becomes an egg, leaving the post-ovulatory follicle complex irregular (Figs. 2M-O). Follicle cells and theca cells were observed in the complex.

Reproductive phases and oocyte development based on light microscopy diagnosis were described and recorded (Table 3; Figure 3).

TABLE 3: Diagnosis of the reproductive phases of L. platymetopon females from the upper Paraná River floodplain.

Phases

\section{Light microscopy diagnosis}

This phase was characterized by the abundant presence of primary growth oocytes and early

Developing secondary growth oocytes and some intermediate secondary growth oocytes (Fig. 3A-F). After regenerating in the beginning of development, some post-ovulatory follicle complexes may be present.

The presence of primary growth oocytes, early, intermediate and final secondary growth oocytes,

Spawning capable full-grown oocytes, oocyte maturation, atresic follicles and post-ovulatory follicle complex was verified in this phase (Fig. 3G-I).

Regressing

Primary growth oocytes, early and final secondary growth oocytes, atresic follicles and several post-ovulatory follicle complexes were recorded (Fig. 3J-L).

Regenerating
The abundant presence of oogonia, oogonial and oocytes nests, and primary growth oocytes was verified. Post-ovulatory and atresic follicles were also observed in this phase (Fig. 3M-O). 
FIGURE 3: Light microphotography of the ovarian histology representative of the reproductive phases of L. platymetopon from the upper Paraná River floodplain.
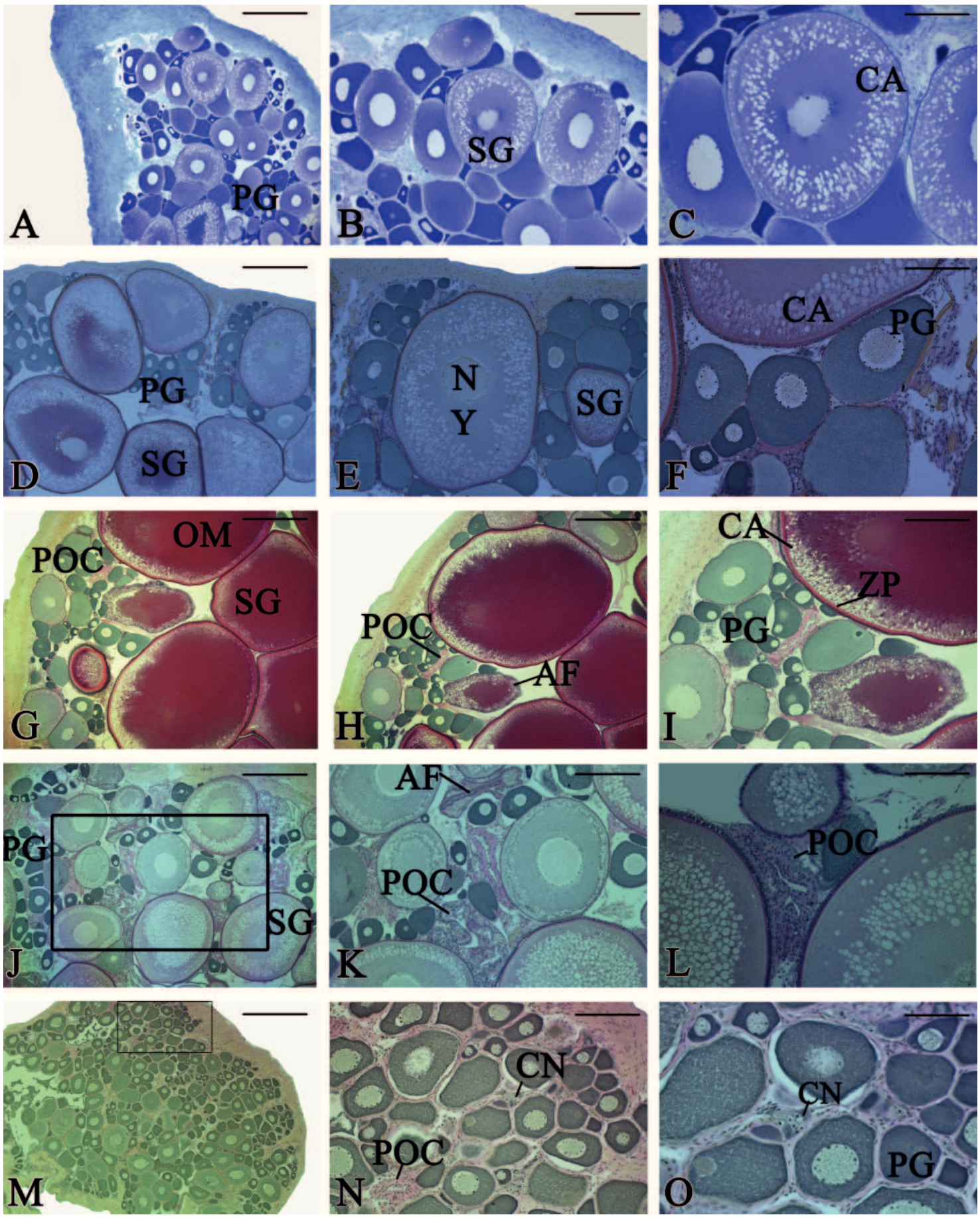

Legend: A-F. Developing, showing primary growth oocytes (PG) and secondary growth oocytes (SG), bars A $=560 \mu \mathrm{m}, \mathrm{B}=280 \mu \mathrm{m}$, $\mathrm{C}=140 \mu \mathrm{m} ; \mathrm{D}=560 \mu \mathrm{m}, \mathrm{E}=280 \mu \mathrm{m}$ and $\mathrm{F}=140 \mu \mathrm{m} ; \mathrm{G}-\mathrm{I}$. Spawning capable, in which primary growth oocytes (PG), secondary growth oocytes (SG), oocyte maturation $(\mathrm{OM})$, a post-ovulatory follicle complex (POC) and an atresic follicle (AF) are seen, bars $\mathrm{G}=560 \mu \mathrm{m}, \mathrm{H}=560 \mu \mathrm{m}$ and $\mathrm{I}=280 \mu \mathrm{m} ; \mathbf{J}-\mathbf{L}$. Regressing, in which there are primary growth oocytes (PG), secondary growth oocytes (SG), atresic follicles and several post-ovulatory follicle complexes (POC), indicating spawning, bars $\mathrm{J}=560 \mu \mathrm{m}, \mathrm{K}=280 \mu \mathrm{m}$ and $\mathrm{L}=140 \mu \mathrm{m}$. M-O. Regenerating, which shows primary growth oocytes (PG), a cell nest (CN) with oogonia and a post-ovulatory follicle complex (POC) being reabsorbed, bars $\mathrm{M}=560 \mu \mathrm{m}, \mathrm{N}=280 \mu \mathrm{m}, \mathrm{O}=70 \mu \mathrm{m}, \mathrm{CA}$, cortical alveoli, N, nucleus, Y, yolk and ZP, zona pellucida. Staining: Toluidine Blue (A-C) and PAS+hematoxylin+metanil yellow (D-O). 
Different processes of degeneration of ovarian follicles (atresia) were observed in the secondary growth follicles of L. platymetopon (Figure 2P-R).

The ovary showed germ compartments in the form of lamellae protruding into the internal ovarian cavity. This cavity is continuous with the oviduct. In this species, ovulation in adults occurs in the internal ovarian cavity and the communication of the ovary to the exterior is through the urogenital papilla and is classified as cystovarian.

The oocyte diameters varied from 100 to $4100 \mu \mathrm{m}$ (Figure 4); however, the distribution of diameters shows that L. platymetopon possesses synchronous oocyte development, with partial spawning and indeterminate fecundity. Batch fecundity $\left(\mathrm{F}_{\mathrm{B}}\right)$ varied from 372 to 1392 oocytes $($ mean $=814 ; \mathrm{SD}=315)($ Table 4$)$.

The estimate of relative batch fecundity by weight was 3.6 to 6.4 oocytes. $\mathrm{g}^{-1}($ mean $=4.8 ; \mathrm{SD}=0.94)$. The estimate of relative batch fecundity by length was 16 to 49 oocytes.cm ${ }^{-1}($ mean $=30 \pm 9.93 \mathrm{SD})($ Table 4$)$.

Relative batch fecundity is positively correlated with the total weight and the standard length of $L$. platymetopon, so that the larger the individual, the higher its fecundity (Figure 5). It should be noted that the total weight possesses a larger coefficient of determination than the standard length $\left(\mathrm{R}^{2}=0.77\right.$ and $\mathrm{R}^{2}=0.68$, respectively).

FIGURE 4: Frequency of the diameter of the oocytes of L. platymetopon from the upper Paraná River floodplain.

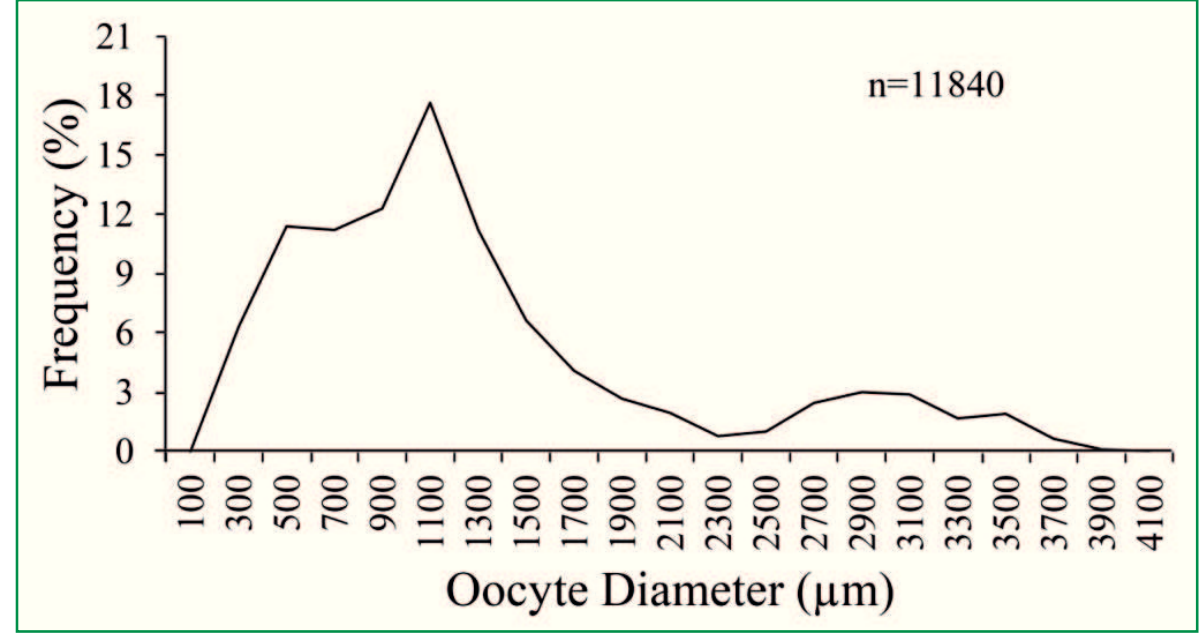

TABLE 4: Overview of reproductive strategies of L. platymetopon from the upper Paraná River floodplain.

\begin{tabular}{|c|c|c|c|c|}
\hline & Sample size & Minimum & Maximum & Mean \pm SD \\
\hline Female standard length $(\mathrm{cm})$ & 1101 & 5.8 & 29.5 & $22.3 \pm 3.73$ \\
\hline Batch fecundity $\left(\mathrm{F}_{\mathrm{B}}\right)$ & 18 & 372 & 1392 & $814 \pm 315$ \\
\hline Relative batch fecundity $\left(\mathrm{g}^{-1}\right)$ & 18 & 3.6 & 6.4 & $4.8 \pm 0.94$ \\
\hline Relative batch fecundity $\left(\mathrm{cm}^{-1}\right)$ & 18 & 16 & 49 & $30 \pm 9.93$ \\
\hline Egg size $(\mu \mathrm{m})$ & 11840 & 100 & 4100 & \\
\hline Oocyte recruitment & Indeterminate & & & \\
\hline
\end{tabular}


FIGURE 5: Relation between relative batch fecundity and total weight (A)/standard length (B) of L. platymetopon from the upper Paraná River floodplain.

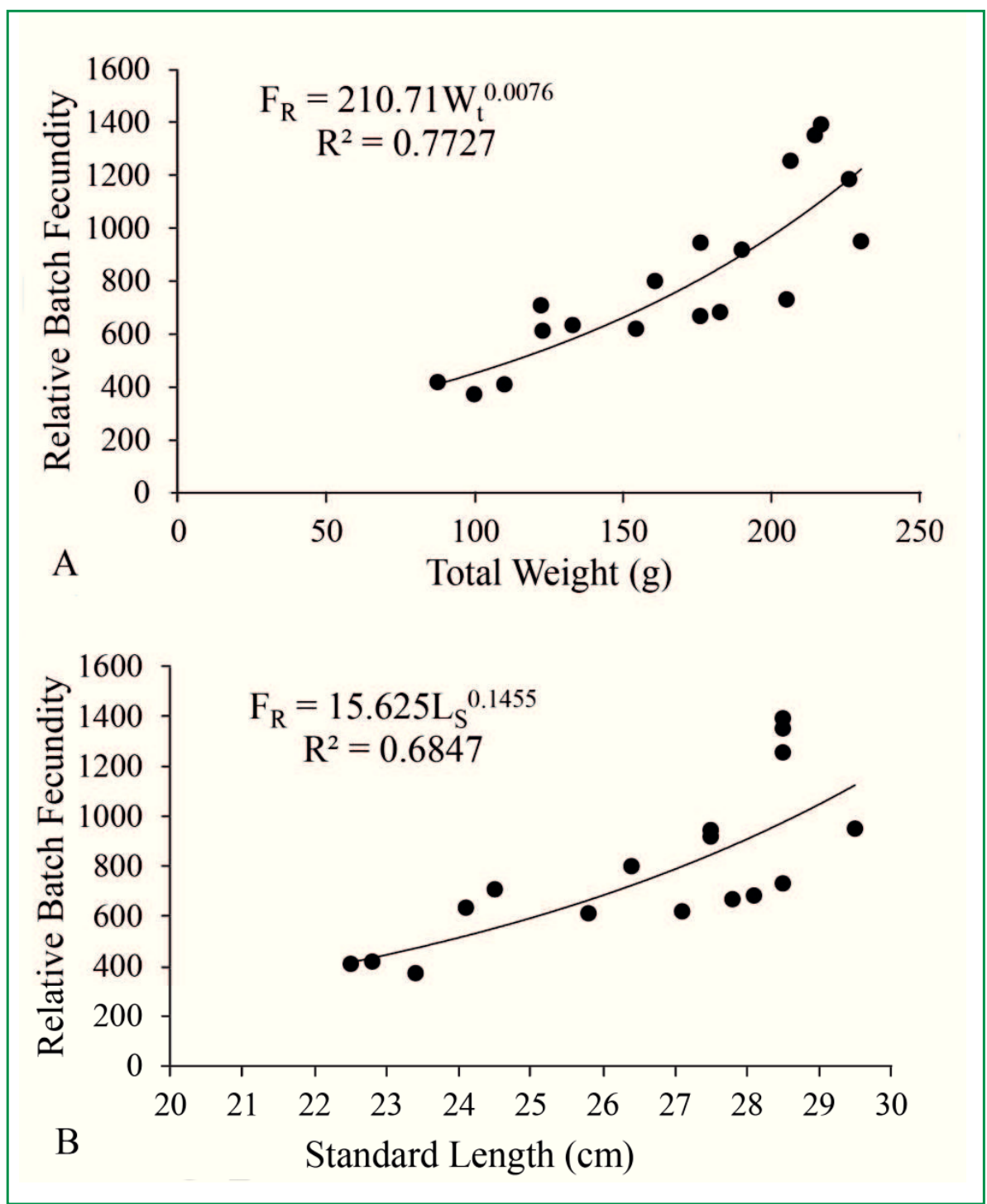

The frequency of individuals in different reproductive phases per sampling site revealed reproductive success in Guaraná and Fechada lagoons and the Baía River $(\mathrm{n}=678)$, followed by Garças and Pau Véio lagoons $(n=250)$ (Figure 6A). A smaller number of individuals were found in Patos and Ventura lagoons and the Ivinheima and Paraná rivers $(n=173)$. Light microscopy confirmed the reproduction areas of this species (Figure 6B). 
FIGURE 6: Number of female individuals in the different gonadal development phases of L. platymetopon at the sites associated with the Ivinheima (Patos Lagoon, Ventura Lagoon and the Ivinheima River), Baía (Fechada Lagoon, Guaraná Lagoon and the Baía River) and Paraná (Garças Lagoon, Pau Véio Lagoon and the Paraná River) rivers of the upper Paraná River floodplain.

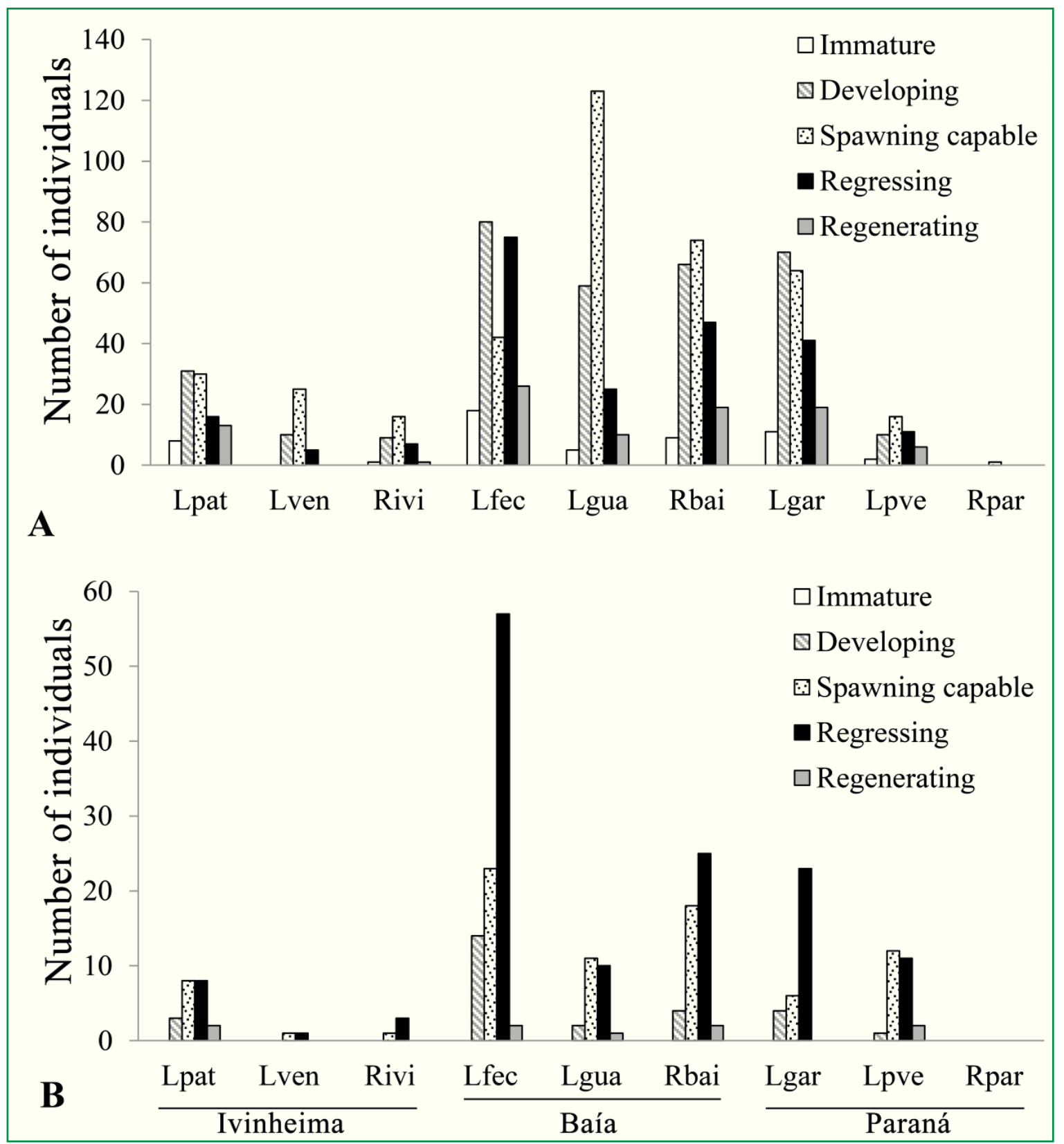

Legend: A = Macroscopic evaluation and B = Light microscopy evaluation. Lpat = Patos Lagoon; Lven = Ventura Lagoon; Rivi = Ivinheima River; Lfec $=$ Fechada Lagoon; Lgua $=$ Guaraná Lagoon; Rbai = Baía River; Lgar = Garças Lagoon; Lpve = Pau Véio Lagoon; Rpar $=$ Paraná River.

\section{Discussion}

The studies conducted in Itaipu Reservoir and on the upper Paraná River floodplain in lentic, semilotic and lotic environments show that L. platymetopon occurs in larger abundance in lentic and semilotic environments of the floodplain (DEI TOS et al., 1997). These authors also found intense reproductive activity in Patos Lagoon, the Baía River, Garças Lagoon and Guaraná Lagoon. However, the same authors found in subsequent years 
that reproduction was more intense in Patos Lagoon and moderate in the Ivinheima River and Garças Lagoon. On the other hand, studies conducted on the floodplain from October/1986 to September/1998 and May/1992 to February/1995 revealed that more than $30 \%$ of the individuals reproduced in the Ivinheima and Iguatemi rivers and about 10 to $30 \%$ in the Paraná and Baía rivers, in the Corutuba and Cortado channels and in Patos and Garças lagoons (SUZUKI et al., 2004). The results showed greater reproductive activity in Guaraná and Fechada lagoons and the Baía River, guaranteeing reproductive success. On the other hand, reproductive activity was less intense in the Ivinheima and Paraná rivers. This indicates possible factors that can bar the invasion of this species or even factors that can facilitate it. Since access to the sites is similar, it is possible that local factors are responsible for limiting reproductive activity in some environments. A possible explanation is the biotic resistance (HENRIKSSON et al., 2015) of the Ivinheima River, because the diversity at this site is very high and, as a state park, the fauna is protected (since 1998), thus maintaining its original characteristics. Another factor that explains less reproductive activity in these rivers is that lotic environments may limit male egg-carrying.

Knowledge of these reproductive patterns helps explain how this species has been so successful invading this site. Loricariidae is among the families that possess the greatest number of invasive species in the Neotropical region, so many that its species successfully inhabit the most varied freshwater habitats (ORTEGA et al., 2015; GUBIANI et al., 2018). The reasons for this success are the reproductive behavior and the plasticity found in reproductive parameters like reproduction sites, time of the year and fecundity. In addition to reproducing at various sites, the species cares for its offspring, thus guaranteeing greater reproductive success.

The terminology applied to describe the germ cells of the ovary of Loricariichthys castaneus in Lajes Reservoir (state of Rio de Janeiro), based on light microscopy, was primary oocytes, previtellogenic oocytes, cortical vesicle oocytes and vitellogenic oocytes (DUARTE et al., 2007). The classifications of these authors were based on macroscopic and light microscopy characteristics of the male and female gonads and attributed to the reproductive cycle phases rest, initial maturation, advanced maturation, partially spent/spawned and totally spent/spawned. However, for the same reservoir and species, the following germ cell stages were identified: oogonia, chromatin nucleolar, perinucleolar, yolk-vesicle formation, vitellogenesis, ripe and post-ovulatory follicles (GOMES et al., 2011). They also recognized immature, maturing, ripe, spawn/ spent and recovering as phases of sexual maturation considering macroscopic and light microscopy aspects of the gonads. As regards Loricariichthys melanocheilus, based on macroscopic evaluation and quantitative indices, recognized phases were: immature, developing, mature and spent for the Ibicuí River (state of Rio Grande do Sul) (ZARDO; BEHR, 2015). In addition, based on the macroscopic evaluation of the gonads of L. platymetopon from Capivara Reservoir in the Paranapanema River, the phases immature, initial maturation, mature, partially-spawned, spent and resting were used (MARCUCCI et al., 2005).

The terminologies used to attribute reproductive phases vary considerably according to the literature. We used immature, developing, spawning capable, regressing and regenerating (BROWN-PETERSON et al., 2011). It is our understanding that this classification is more appropriate because it improves and simplifies the terminologies and applies to L. platymetopon, according to the renewal, development, differentiation, maturation and liberation of its gametes. This classification of freshwater fish has been used in Brazil to attribute the gonadal development phases of Pimelodus maculatus and Serrasalmus maculatus (WILDNER et al., 2013), Pimelodus maculatus (BRANDÃO et al., 2014), Atlantirivulus riograndensis (CAVALHEIRO; FIALHO, 2015), Salminus brasiliensis (BARZOTTO; MATEUS, 2017), Pseudotocinclus tietensis (RODRIGUES-FILHO et al., 2017) and Serrasalmus marginatus (MELO et al., 2017).

In the upper Paraná River, first maturation size of L. platymetopon was estimated to be $13.6 \mathrm{~cm}$ for males and $14.6 \mathrm{~cm}$ for females and all individuals were adults at a standard length of $19.0 \mathrm{~cm}$. Males reached a standard length of $28.2 \mathrm{~cm}$ and females $33.6 \mathrm{~cm}$ (DEI TOS et 
al., 1997). Studies conducted in another period on the upper Paraná River floodplain revealed first maturation size to be $15.7 \mathrm{~cm}$ and $14.5 \mathrm{~cm}$ for females and males, respectively, and maximum standard length was $33.6 \mathrm{~cm}$ (SUZUKI et al., 2004). Studies carried out in the stretch between the Paranapanema and Iguaçu rivers showed that L. platymetopon was common in floodplain lagoons and rare in Itaipu Reservoir and its tributaries (DEI TOS et al., 1997; SUZUKI et al., 2000). According to Suzuki et al. (2000), this species has synchronous oocyte development in batches. The mean oocyte diameter was $2320 \mu \mathrm{m}$ and relative fecundity (of the batch) was 9.46 oocytes. $\mathrm{g}^{-1}$ body weight. Studies of $L$. platymetopon in Capivara Reservoir, situated in the middle stretch of the Paranapanema River, show that the mean diameter of the mature oocyte was $3330 \mu \mathrm{m}$, while the maximum diameter was $4140 \mu \mathrm{m}$. Absolute fecundity varied from 464 to 850 (mean $=663.95 \pm 141.99$ oocytes $)$ (MARCUCCI et al., 2005). These authors found relative fecundity by weight to be between 3.2 and 7.5 oocytes. $\mathrm{g}^{-1}$ $\left(\right.$ mean $=4.9 ; \mathrm{SD} \pm 1.24$ oocytes. $\left.\mathrm{g}^{-1}\right)$. Bailly et al. (2011) recorded the diameter of oocytes varying between 1380 and $2160 \mu \mathrm{m}($ mean $=1670)$ in Saraiva Lagoon. The estimated absolute fecundity varied from 522.9 to 1594.6 oocytes (mean $=962.1 ; \mathrm{SD} \pm 382.48$ oocytes). Relative fecundity was $7.60(\mathrm{SD} \pm 2.25)$ oocytes. $\mathrm{g}^{-1}$ and $5.13(\mathrm{SD} \pm 0.75)$ oocytes. $\mathrm{cm}^{-1}$. There was little variation between our results and those obtained in the above investigations in different periods and regions, indicating a conservative strategy. This conservative strategy may explain the ease that this species has in colonizing these sites, since all have similar characteristics, both in relation to the flow and the history of environmental formation, going from lotic to lentic. Therefore, the probability of invasion success is similar for several environments, since the species also has a consistent physiological and behavioral pattern, as indicated in the results discussed here.

We conclude that evaluation of fecundity by weight and length, associated with information about reproductive areas based on macroscopic and light microscopy evaluation of the ovary, is an efficient management tool to show variations in the reproductive cycle. The individuals of this species are sedentary, possess a detritivorous feeding habit, predominate in lentic environments, generally reproduce in these environments, show synchronous oocyte development, are batch spawners and the males carry the eggs under the lower lip (FUGI et al., 1996; DEI TOS et al., 1997; SUZUKI et al., 2000; HAHN et al., 2004). These ecological characteristics permit their occupation and reproductive success on the floodplain, especially in the lagoons, as these attributes give them competitive advantages over the natives. Thus, the biotic resistance of the Ivinheima River, due to the integrity of this environment, which is part of the Environmental Protection Area of the Islands and Marshes of the Paraná River (Área de Proteção Ambiental das Ilhas e Várzeas do Rio Paraná), has prevented the reproductive success of this invader.

\section{Acknowledgments}

The authors thank Prof. Liliana Rodrigues, coordinator of PELD (upper Paraná River floodplain) for partial financial support, the researchers and technicians of the Núcleo de Pesquisas em Limnologia, Ictiologia e Aquicultura, Prof. Talita Sarah Mazzoni from Universidade Federal de Alfenas for technical-scientific support, the Fundação Araucária and CNPq for granting scientific initiation scholarships to Camila A. Cardim and Vanessa de Brito Pereira, the Complexo de Centrais de Apoio à Pesquisa/UEM for help with equipment, Prof. Roger Paulo Mormul from Universidade Estadual de Maringá for financial support and anonymous reviewers for their suggestions.

\section{References}

ABELL, R.; THIEME, M. L.; REVENGA, C.; BRYER, M.; KOTTELAT, M.; BOGUTSKAYA, N.; COAD, B.; MANDRAK, N.; BALDERAS, S. C.; BUSSING, W.; STIASSNY, M. L. J.; SKELTON, P.; ALLEN, G. R.; UNMACK, P.; NASEKA, A.; NG, R.; SINDORF, N.; ROBERTSON, J.; ARMIJO, E.; HIGGINS, J. V.; HEIBEL, T. J.; WIKRAMANAYAKE, E.; OLSON, D.; LÓPEZ, H. L.; REIS, R. E.; LUNDBERG, J. G.; PÉREZ, M. H. S.; PETRY, P. Freshwater ecoregions of the world: a new map of biogeographic units for freshwater biodiversity conservation. BioScience, Berkeley, v. 58, n. 5, p. 403-414, 2008.

AGOstinho A. A.; GOMES, L. C.; PELICICE, F. M. Ecologia e manejo de recursos pesqueiros em reservatórios do Brasil. Maringá: Eduem, 2007. 501 p. 
AGOSTINHO A. A.; ZALEWSKI, M. A planície alagável do alto rio Paraná: importância e preservação. Maringá: EDUEM, 1996. $100 \mathrm{p}$.

BAILLY, D.; BATISTA-SILVA, V. F.; ABELHA, M. C. F.; KASHIWAQUI, E. A. L.; FERNANDES, C. A.; CARVALHO, E. D. Relative abundance and reproductive tactics of a Loricariidae species at Saraiva Lagoon, Ilha Grande National Park, MS-PR, Brazil. Biota Neotropica, Campinas, v. 11, n. 3, p. 171-178, 2011.

BARNEY, J. N.; WHITLOW, T. H. A unifying framework for biological invasions: the state factor model. Biological Invasions, Dordrecht, v. 10, n. 3, p. 259-272, 2008.

BARZOTTO, E.; MATEUS, L. Reproductive biology of the migratory freshwater fish Salminus brasiliensis (Cuvier, 1816) in the Cuiabá River basin, Brazil. Journal of Applied Ichthyology, Berlin, v. 33, n. 3, p. 415-422, 2017.

BRANDÃO, H.; SANTANA, J. C. de O.; RAMOS, I. P.; CARVALHO, E. D. Influence of cage farming on feeding and reproductive aspects of Pimelodus maculatus Lacépède, 1803 (Siluriformes: Pimelodidae) in the Chavantes reservoir, Brazil. Acta Scientiarum. Biological Sciences, Maringá, v. 36, n. 1, p. 41-50, 2014

BROWN-PETERSON, N. J.; WYANSKI, D. M.; SABORIDOREY, F.; MACEWICZ, B. J.; LOWERRE-BARBIERI, S. K. A standardized terminology for describing reproductive development in fishes. Marine and Coastal Fisheries: Dynamics, Management and Ecosystem Science, Bethesda, v. 3, n. 1, p. 52-70, 2011.

CASIMIRO A. C. R.; GARCIA, D. A. Z.; COSTA, A. D. A.; BRITTON, J. R.; ORSI, M. L. Impoundments facilitate a biological invasion: dispersal and establishment of non-native armoured catfish Loricariichthys platymetopon (Isbrückler \& Nijssen, 1979) in a neotropical river. Limnologica - Ecology and Management of Inland Waters, Bariloche, v. 62, p. 34-37, 2017.

CAVALHEIRO, L. W.; FIALHO, C. B. Reproductive strategy of a non-annual rivulid in a perennial wetland Laísa. Iheringia, Série Zoologia, Porto Alegre, v. 105, n. 3, p. 288-296, 2015.

DEI TOS, C.; AGOSTINHO, A. A.; SUZUKI, H. I. Population structure and reproductive biology of Loricariichthys platymetopon (Silurifomes, Pisces) in the upper River Paraná. Brazilian Archives of Biology and Technology, Curitiba, v. 40, n. 4, p. 793-807, 1997. DUARTE, S.; ARAÚJO, F. G.; SALES, A.; BAZZOLI, N. Morphology of gonads, maturity and spawning season of Loricariichthys spixii (Siluriformes, Loricariidae) in a subtropical Reservoir. Brazilian Archives of Biology and Technology, Curitiba, v. 50, n. 6, p. 1019-1032, 2007.

FUGI, R.; HAHN, N. S.; AGOSTINHO, A. A. Feeding styles of five species of bottom-feeding fishes of the high Paraná River. Environmental Biology of Fishes, New York, v. 46, n. 3, p. $297-$ 307, 1996.

GALLARDO, B.; CLAVERO, M.; SÁNCHEZ, M. I.; VILÀ, M. Global ecological impacts of invasive species in aquatic ecosystems. Global Change Biology, Medford, v. 22, n. 1, p. 151-163, 2016.

GOMES, I. D.; ARAUJO, F. G.; UEHARA, W.; SALES, A. Reproductive biology of the armoured catfish Loricariichthys castaneus (Castelnau, 1855) in Lajes reservoir, southeastern Brazil. Journal of Applied Ichthyology, Berlin, v. 27, p. 1322-1331, 2011. GRIER, H. J.; URIBE-ARANZÁBAL, M. C.; PATIÑO, R. The ovary, folliculogenesis, and oogenesis in teleosts. In: JAMIESON,
B. G. M. (Ed.). Reproductive Biology and Phylogeny of fishes (Agnathans and bony fishes): phylogeny, reproductive system viviparity, spermatozoa. Enfield: Science Publisher, 2009. p. 25-84. GUBIANI, É.A.; RUARO, R.; RIBEIRO, V. R.; EICHELBERGER, A. C. A.; BOGONI, R. F.; LIRA, A. D; CAVALLI, D.; PIANA, P. A.; GRAÇA, W. J. DA. Non-native fish species in Neotropical freshwaters: how did they arrive, and where did they come from? Hydrobiologia, Brussels v. 817, n. 1, p. 57-69, 2018.

HAHN, N. S.; FUGI, R.; ANDRIAN, I. F. Trophic ecology of the fish assemblages. In: THOMAZ, S. M.; AGOSTINHO, A. A.; HAHN, N. S. (Ed.). The upper Paraná River and its floodplain. Liedman: Backhuys Publishers, 2004. p. 247-269.

HENRIKSSON, A.; YU, J.; WARDLE, D. A.; ENGLUND, G. Biotic resistance in freshwater fish communities: species richness, saturation or species identity? Oikos, Copenhagen, v. 124, n. 8, p. 1058-1064, 2015.

JULIO JR., H. F.; DEI TOS, C.; AGOSTINHO, A. A.; PAVANELLI, C. S. A massive invasion of fish species after eliminating a natural barrier in the upper rio Paraná basin. Neotropical Ichthyology, Maringá, v. 7, n. 4, p. 709-718, 2009.

MARCUCCI, K. M. I.; ORSI, M. L.; SHIBATTA, O. A. Abundância e aspectos reprodutivos de Loricariichthys platymetopon (Siluriformes, Loricariidae) em quatro trechos da represa Capivara, médio rio Paranapanema. Iheringia, Série Zoologia, Porto Alegre, v. 95, n. 2, p. 197-203, 2005.

MCBRIDE, R. S.; SOMARAKIS, S.; FITZHUGH, G. R.; ALBERT, A.; YARAGINA, N. A.; WUENSCHEL, M. J.; ALONSO-FERNÁNDEZ, A.; BASILONE, G. Energy acquisition and allocation to egg production in relation to fish reproductive strategies. Fish and Fisheries, Vancouver, v. 16, n. 1, p. 23-57, 2015.

MELO, S. R. de; SANTANA, H. S. DE; DEI TOS, C. Ovarian histology and fecundity in the evaluation of the reproduction of the invasive species Serrasalmus marginatus (Characidae) on a neotropical floodplain. Acta Scientiarum. Biological Sciences, Maringá, v. 39, n. 3, p. 339-347, 2017.

MELlO, M. L.; VIDAL, B. C. Práticas de Biologia Celular. São Paulo: Edgard Blucher. 1980. 66 p.

MURUA, H.; KRAUS, G.; SABORIDO-REY, F.; WITTHAMES, P. R.; THORSEN, A.; JUNQUEIRA, S. Procedures to estimate fecundity of marine fish species in relation to their reproductive strategy. Journal of Northwest Atlantic Fishery Science, Bergen, v. 33, p. 33-54, 2003.

NAKATANI, K.; AGOSTINHO, A. A.; BAUMGARTNER, G.; BIALETZKI, A., SANCHES, P. V.; MAKRAKIS, M. C.; PAVANELLI, C. S. Ovos e larvas de peixes de água doce: desenvolvimento e manual de identificação. Maringá: EDUEM, 2001. 378 p.

OLIVEIRA, E. F. de; LUIZ, E. A.; AGOSTINHO, A. A.; BENEDITO-CECILIO, E. Fish assemblages in littoral areas of the upper Paraná river floodplain, Brazil. Acta Scientiarum, Maringá, v. 23, n. 2, p. 369-376, 2001.

ORTEGA, J. C. G.; JÚLIO JR, H. F.; GOMES, L. C.; AGOSTINHO, A. A. Fish farming as the main driver of fish introductions in Neotropical reservoirs. Hydrobiologia, Brussels, v. 746, n. 1, p. 147-158, 2015. 
PEJCHAR, L.; MOONEY, H. A. Invasive species, ecosystem services and human well-being. Trends in Ecology and Evolution, Cambridge, v. 24, n. 9, p. 497-504, 2009.

QUAGIO-GRASSIOTTO, I.; GRIER, H.; MAZZONI, T. S.; NOBREGA, R. H.; AMORIM, J. P. de A. Activity of the ovarian germinal epithelium in the freshwater catfish, Pimelodus maculatus (Teleostei: Ostariophysi: Siluriformes): germline cysts, follicle formation and oocyte development. Journal of Morphology, Malden, v. 272, n. 11, p. 1290-1306, 2011.

QUAGIO-GRASSIOTTO, I.; WILDNER, D. D.; ISHIBA, R. Gametogênese de peixes: aspectos relevantes para o manejo reprodutivo. Revista Brasileira de Reprodução Animal, Belo Horizonte, v. 37, n. 2, p. 181-191, 2013.

QUEROL, M. V. M.; QUEROL, E.; GOMES, N. N. A. Fator de condição gonadal, índice hepatossomático e recrutamento como indicadores do período de reprodução de Loricariichthys platymetopon (Osteichthyes, Loricariidae), bacia do rio Uruguai médio, Sul do Brasil. Iheringia, Série Zoologia, Porto Alegre, v. 92, n. 3, p. 79-84, 2002.

QUEROL, M. V. M.; QUEROL, E.; PASSOS, V. M. Estudo preliminar do cascudo Loricariichthys platymetopon (Isbrucker \& Nijssen, 1979) (Siluriformes, Loricariidae) visando seu aproveitamento comercial na região de Uruguaiana, RS, Brasil. Revista da FAVA, Uruguaiana, v. 2/3, n. 1, p. 110-117, 1996.

QUINTERO-HUNTER, I.; GRIER, H.; MUSCATO, M. Enhancement of histological detail using metanil yellow as a counterstain in periodic acid/Schiff's hematoxylin staining of glycol methacrylate tissue sections. Biotechnic Histochemistry, Ontario, v. 66, n. 4, p. 169-172, 1991.

REIS, R. E.; PEREIRA, E. H. L. Three new species of the loricariid catfish genus Loricariichthys (Teleostei: Siluriformes) from southern South America. Copeia, Lawrence, v. 4, p. 1029-1047, 2000.

REYNALTE-TATAJE D. A.; AGOSTINHO A. A.; BIALETZKI A. Temporal and spatial distribution of the fish larval assemblages of the Ivinheima River sub-basin (Brazil). Environmental Biology of Fishes, New York, v. 96, p. 811-822, 2013.

RODRIGUES-FILHO, J. A.; HONHI, R. M.; MELLO, P. H.; BORELLA, M. I.; HILSDORF, A. W. S.; MOREIRA, R. G. Reproductive biology of Pseudotocinclus tietensis (Siluriformes: Loricariidae: Hypoptopomatinae), a threatened fish species. International Journal of Aquatic Biology, Tehran, v. 5, n. 3, p. 218-227, 2017.

SIMBERLOFF, D.; MARTIN, J-L.; GENOVESI, P.; MARIS, V.; WARDLE, D. A.; ARANSON, J.; COURCHAMP, F.; GALIL, B.; GARCÍA-BERTHOU, E.; PASCAL, M.; PYSEK, P.; SOUSA, R.; TABACCHI, E.; VILÀ, M. Impacts of biological invasions: what's what and the way forward. Trends in Ecology \& Evolution, Cambridge, v. 28, n. 1, p. 58-66, 2013.
SKÓRA, F.; ABILHOA, V.; PADIAL, A. A.; VITULE, J. R. S. Darwin's hypotheses to explain colonization trends: evidence from a quasi-natural experiment and a new conceptual model. Diversity and Distributions, Stellenbosch, v. 21, n. 5, p. 583-594, 2015.

SOUTO, A. C.; VIDOTTO-MAGNONI, A. P.; BRANDÃO, H.; RAMOS, I. P.; CARVALHO, E. D. Actinopterygii, Siluriformes, Loricariidae, Loricariichthys platymetopon Isbrücker and Nijssen, 1979: First record in reservoir of Canoas II, Middle Paranapanema river, border of the states of São Paulo and Paraná, Brazil. Check List, Rio Claro, v. 7, n. 3, p. 279-281, 2011.

SUZUKI, H. I.; AGOSTINHO, A. A.; WINEMILLER, K. O. Relationship between oocyte morphology and reproductive strategy in loricariid catfishes of the Paraná River, Brazil. Journal of Fish Biology, Malden, v. 57, n. 3, p. 791-807, 2000.

SUZUKI, H. I.; VAZZOLER, A. E. A. M.; MARQUES, E. E.; LIZAMA, M. A. P.; INADA, P. Reproductive ecology of the fish assemblages. In: THOMAZ, S. M.; AGOSTINHO, A. A.; HAHN, N. S. (Ed.). The upper Paraná River and its floodplain. Liedman: Backhuys Publishers, 2004. p. 271-291.

TONELLA, L. H.; FUGI, R.; VITORINO JR., O. B.; SUZUKI, H. I.; GOMES, L. C.; AGOSTINHO, A. A. Importance of feeding strategies on the long-term success of fish invasions. Hydrobiologia, Brussels, v. 817, n. 1, p. 239-252, 2018.

VAZZOLER, A. E. A. M. Biologia da reprodução de peixes teleósteos: teoria e prática. Maringá: Eduem, 1996. 169 p.

VIDAL, B. C. Métodos em Biologia Celular. In: VIDAL, B. C.; MELLO, M. L. (Ed.). Biologia Celular. Rio de Janeiro: Atheneu, 1987. p. 485-494.

WILDNER, D. D.; GRIER, H.; QUAGIO-GRASSIOTTO, I. Female germ cell renewal during the annual reproductive cycle in Ostariophysians fish. Theriogenology, Worburn, v. 79, n. 4, p. 709$724,2013$.

WOOTTON, R. J. Introduction: strategies and tactics in fish reproduction. In: POTTS, G. W.; WOOTTON, R. J. (Ed.). Fish reproduction: strategies and tactics. London: Academic Press, 1984. p. 1-12.

ZARDO, E. Z.; BEHR, E. R. Population structure and reproductive biology of Loricariichthys melanocheilus Reis \& Pereira, 2000 (Siluriformes: Loricariidae) in the rio Ibicuí, Brazil. Neotropical Ichthyology, Maringá, v. 13, n. 2, p. 371-382, 2015. 